\title{
Developing Interactive Digital Mathematics Book with Multi Representation Approach for Deaf Students
}

\author{
https://doi.org/10.3991/ijet.v16i13.22459 \\ I Made Suarsana \\ Universitas Pendidikan Ganesha, Singaraja, Bali \\ made.suarsana@undiksha.ac.id
}

\begin{abstract}
Mathematics learning objectives for deaf students is not different from normal students, but their learning approach is not same. Learning materials for deaf students should be made simple and equipped with multi representation. With the development of ICT, multi representation has become easy and inexpensive. Therefore, the purpose of this study was to develop an interactive digital book with multi representation approach for deaf students. This study was carried out using 3 initial stages of 4-D research and development design (define, design, develop, and disseminate). Media feasibility is determined based on the results of expert validation, practicality test, and passing grade. The average score of book validation by the material expert was $2.92(97.3 \%)$, learning design expert was 2.97 (99\%), media expert was 2.99 (99.7\%), and language expert was $2.78(92.7 \%)$, so it can be said that the book met the validity criteria. The average score of the practicality test by students was 4.24 $(84.8 \%)$ and teachers was $4.35(87 \%)$, so it can be said that the book met the practicality criteria. The average passing grade was $83.34 \%$, so the book met the effectiveness criteria. By meeting validity, practicality, and effectiveness criteria, it can be concluded that the digital book met the feasibility criteria as mathematical learning materials for VII-grade deaf students.
\end{abstract}

Keywords - Deaf, mathematics learning, digital book, multi representation

\section{Introduction}

Mathematical learning for deaf students has the same objectives as mathematical learning for normal students, namely to equip students to think systematically, logically, analytically, creatively, critically and capable to collaborate. However, the mathematical learning outcome of deaf students is still very low [1]. This is stated by [2] that several studies indicated low learning performance of deaf students when compared to normal students. For normal students, mathematics is a difficult subject[3]. For deaf students, the problem will be more complicated because of hearing problems [2]. Learning difficulties for students include weakness in absorbing information [4], [5],[6] limitations in interacting with teachers or other students [7], [8] low motivation to learn because they are uncomfortable and frustrated in expressing ideas or questions [9], [10]. 
Mathematical learning for deaf students is certainly different from normal students. Two things that need to be considered are the characteristics of deaf students and the characteristics of mathematics lessons. Deaf students are known as visual learners because they access more information by eye ([8], [11]). Therefore, the subject matter should be made easy and prepared with visual representations [12], [13]. Meanwhile, mathematics is concerned with abstract ideas [13]. Therefore, the presentation of the materials should also be performed as simply as possible and with multi representation [14]-[18]. Mathematical representations may be accomplished with concrete objects, manipulative models, mathematical models, drawings, sketches, tables, diagrams, graphs, and computer simulations [14], [15], [17]

With the fast gain of ICT, the development of multi-representative teaching materials is not difficult and expensive. Recently, interactive digital books have become a trend discussed by many researchers [19]-[21]. An interactive digital book with a multi representation approach for deaf students had been developed by several researchers.

First, previous studies on the development of ICT-based learning resources for deaf students namely, (1) [22] developed e-learning design or courseware based on multiple intelligence theory for learning sign language for beginners, (2) [23] developed sign language courseware for 7-8 years old deaf students. The results found that courseware can help teachers, students, and parents in teaching and learning sign language.

Second, previous studies on the use of multi representation approaches namely, (1) [24] found that student engagement with various forms of physical representations such as verbal, visual, symbolic, mathematics, and hands-on activities such as argumentation and presentation as well as the virtual laboratory increased the mastery of quantum physics concepts, (2) [25] found that chemistry learning became more effective by using a multi-representation approach, (3) [26] found that learning with a multi-representation approach could improve the learning outcome of students on educational statistics, (4) [27] found that a multi-representation based scientific conceptual learning model increased science process skills and mastery of physics concepts, and (5) [28] developed a multi-representation contextual module that increased critical thinking skills of students.

Third, previous studies on the development of learning materials in the form of interactive digital books namely (1) [29], [30] developed digital books for learning genetics in vocational high school, (2) [31] developed folk stories with digital books, (3) [19] maximized online learning with digital books, (4) development of interactive digital book by [31]-[33], (5) [34] developed digital books for learning physics, as well as (6) [35] developed digital books for learning calculus and (7) [36] developed digital books of European History.

Based on the above explanation, a study on an interactive digital book with a multi representation approach for deaf high school students is important to be carried out immediately considering the lack of studies on the development of learning resources for disabled students. The existing learning resource in the form of a textbook which does not accommodate the needs of deaf students as visual learners. The development of an interactive digital book with multi representation approach is the right solution 
to the limitations of learning resources. Digital books can accommodate the characteristics of deaf students and the characteristics of mathematics as an abstract science. Thus, the problem formulation is, how is the feasibility of the developed interactive digital book with multi representation approach based on its validity, practicality, and effectiveness?

\section{Method}

\subsection{Design and procedure of study}

This study used 4-D research and development stages namely define, design, develop, and disseminate [37]. However, this study only described the development stage or development of the learning material prototype after expert and user validation

The first stage is the define stage. In this stage, preliminary analysis and curriculum analysis were carried out. In the preliminary analysis, researchers identified problems in the field of mathematics learning for VII-grade deaf students. Based on interviews and observation with VII-grade teachers, 1) the mathematics learning outcomes of students were low; 2) students have difficulty in understanding the learning material even for basic arithmetic operations; 3 ) the existence of special media for mathematics learning is very limited so that learning tends to use the explanatory method. Based on curriculum analysis, the materials for VII-grade students are fractions, geometry, integers, LCM, and GCD.

The second stage is the design stage. In this stage, the digital book was designed by considering content, displays, and learning strategies by developing storyboards and the initial products of the digital-book. The minimally developed digital book design can (i) imitate the VII-grade electronic school book format from the Ministry of Education and Culture, (ii) present a concept with a multi-representational approach, namely verbal, numeric and visual, (iii) equipped with sign language translation videos, (iv) equipped with computer simulations that can be manipulated by students, and (v) equipped with evaluations in the form of formative tests with direct responses. After the flowchart, the storyboard was realized into Prototype I with several applications such as eXelearning, Microsoft Powerpoint, Sparkol Video, Filmora, Camtasia, and Geogebra.

The third stage is the development stage. This stage aimed to produce a final prototype. To develop feasible learning media, some stages were carried out namely, expert judgement, product revision, and small group testing. The feasibility test aims to find out the feasibility of digital books based on expert validation (media feasibility, learning design feasibility, material feasibility, language feasibility) and user validation. This study involved 2 teachers and 9 students of SMPLB B Negeri Singaraja 2019/2020 in small group testing. SMPLB Negeri 1 Singaraja was chosen due to easy access so that the study can be carried out smoothly. In addition, the facilities and infrastructure in schools are able to accommodate the use of digital book in the classroom. 
The fourth stage is the disseminate stage. This stage is carried out by socializing the developed product so that it can be accepted by users, either individually, in groups, or by the system. The product dissemination process is carried out in various ways, such as socialization and implementation in class to determine the effectiveness of digital books in the learning process. Dissemination can also be performed through an induction process to related learning practitioners in a specific forum. However, this study was only explained to the development stage.

\subsection{Research instrument}

Data collected were data on the feasibility of digital books based on validity (material, learning design, media, language), practice (teacher and student responses as users), and effectiveness (average learning outcomes and percentage of passing). Validity data of digital books were collected with expert validation sheets. There were 5 indicators in the assessment of the material, namely the suitability of the material to the curriculum, suitability of student characteristics, specificity, clarity, accuracy, and suitability of the material with the required teaching materials, suitability with social norms, benefits to adding insight, and balance in the presentation of the material. There were 5 indicators in the assessment on language namely readability, integration of words and sentences, clarity of information, conformity to teaching material development principles, and effectiveness and efficiency of the language used. There were 5 indicators in the assessment on design namely the clarity of the learning objectives, the order of the material presented, arousing student enthusiasm for learning, stimulating student learning activities, and presenting complete information. The media assessment had several indicators namely the use of letters, layout, illustrations, figures, and photos used as well as displays both of the cover and content.

Practicality data from digital books were collected by using questionnaire responses from teachers and students using a Likert scale. The teacher response questionnaire consisted of 20 statements, while students only consisted of 15 statements. These statements relate to ease of use, the attractiveness of the book, benefit and ease of understanding the content. Effectiveness data of the digital book were collected with objective test.

\subsection{Data analysis technique}

There were 2 types of data collected namely quantitative data and qualitative data. Qualitative data relates to input from experts and users directly to improve digital books. Meanwhile, the quantitative data were analyzed using descriptive statistics using average scores and percentages. Digital book is valid if the minimum average validity score was 1.68 , practical if the minimum average practicality score was 2.6 , and effective if the minimum average effectiveness score was 76 with the minimum percentage of classical completeness was $80 \%$ as shown in Table 1 and Table 2 . 
Table 1. Validity Score of Digital Book [38]

\begin{tabular}{|c|c|}
\hline Class & Category \\
\hline $2.36 \leq \bar{V} \leq 3.00$ & Valid \\
\hline $1.68 \leq \bar{V}<2.36$ & Fairly Valid \\
\hline $1 \leq \bar{V}<1.68$ & Not Valid \\
\hline
\end{tabular}

Table 2. Practicality Score of Digital Book [39]

\begin{tabular}{|c|c|}
\hline Class & Category \\
\hline $4.20 \leq \overline{\boldsymbol{P}} \leq 5.00$ & Very High \\
\hline $3.40 \leq \overline{\boldsymbol{P}}<4.20$ & High \\
\hline $2.60 \leq \overline{\boldsymbol{P}}<3.40$ & Medium \\
\hline $1.80 \leq \overline{\boldsymbol{P}}<2.60$ & Low \\
\hline $1.00 \leq \overline{\boldsymbol{P}}<1.80$ & Very Low \\
\hline
\end{tabular}

\section{Result}

\subsection{Results of digital book development}

This study developed the interactive digital book for VII-grade deaf students containing 4 learning topics, namely fractions, geometry, integers, LCM, and GCD. The learning media consists of front pages, materials, instructional videos, instructional media, practice questions, and bibliography. The initial display is a front page which can be seen in Figure 1.

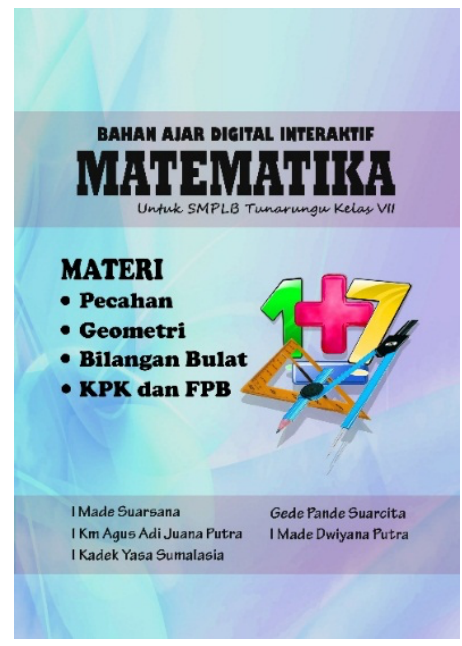

Fig. 1. Front Page of Digital Book 
The next part is a presentation of teaching materials with a multi-representation approach, namely verbal, numerical and visual, video with sign language, and GeoGebra-based exploratory computer simulations. The material is arranged sequentially according to the learning indicators. Display of content/material, instructional videos, and learning media about fractions can be seen in Figure 2, Figure 3, and Figure 4.

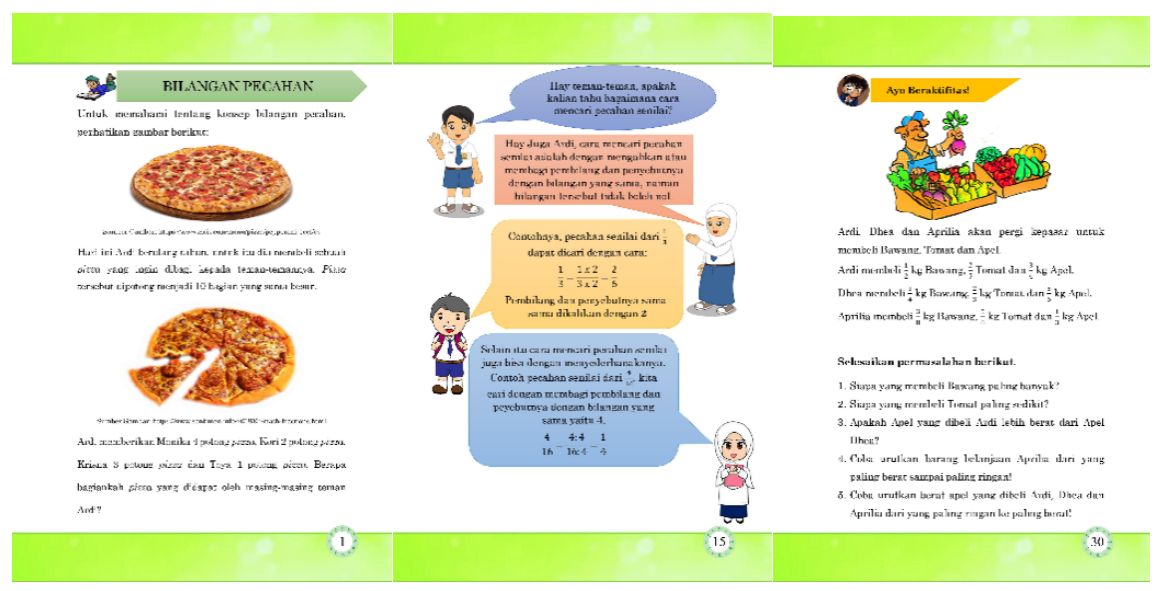

Fig. 2. Display of Material Explanation

Based on Figure 2, material (fractions) is presented using various representations such as real objects in the form of pizza to introduce the concept of fractions, then verbal representations, or stories in the form of conversations between students about fractions, then mathematical symbols of fractions.

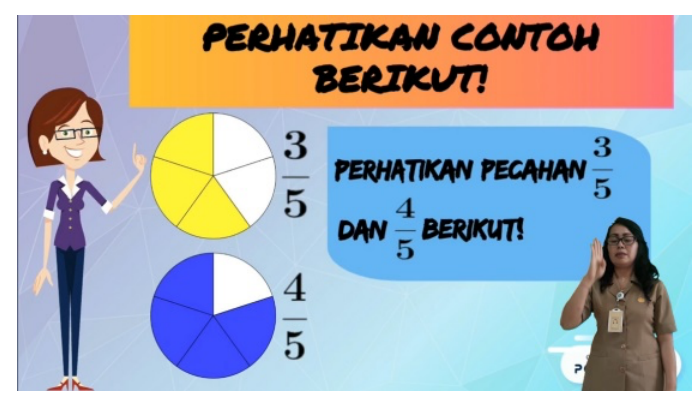

Fig. 3. Display of Learning Videos with Sign Language

Based on Figure 3, the learning media is also represented by learning videos with sign language. As visual learners, the potential possessed by students in absorbing information is visually stimulated through video. This video is equipped with a sign language translator to help students understand the information on the video. 


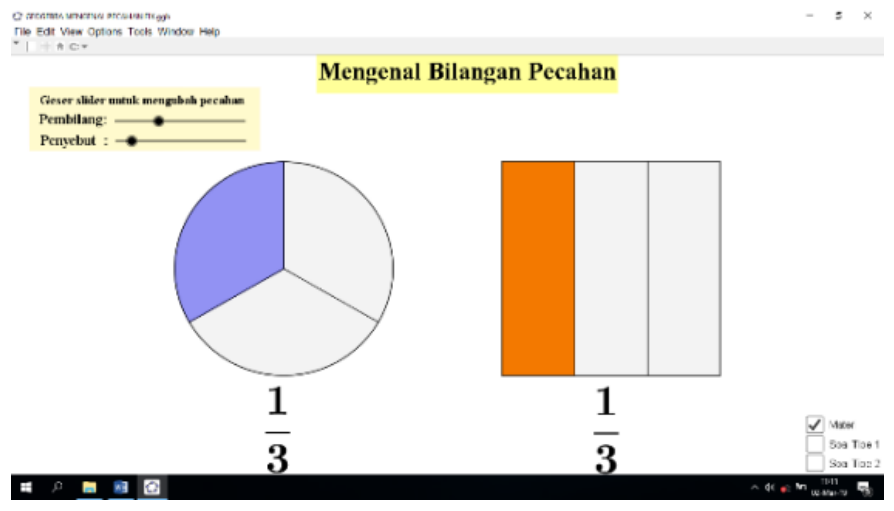

Fig. 4. Display of GeoGebra Simulation

In addition to visual, verbal, numerical representations, and instructional videos, this digital book is equipped with computer simulation representations in the form of dynamic worksheets based on the GeoGebra application. Students can manipulate by moving the cursor and interactively provide input or answers to questions. Immediate feedback to student input is provided by this interactive media. This digital book is equipped with practice questions with interactive live feedback.

\subsection{Results of digital book feasibility}

The developed digital book is feasible if it meets 3 criteria namely validity, practicality, and effectiveness. The assessment results of the digital book can be seen in Table 3.

Table 3. The Validity, Practicality, and Effectiveness of Learning Media

\begin{tabular}{|c|c|c|c|c|c|c|}
\hline No & Aspect & \multicolumn{4}{|c|}{ Score Per Topic } & \multirow[t]{2}{*}{ Average } \\
\hline$A$. & Validity & Fraction & Geometry & Integer & $L C M$ and $G C D$ & \\
\hline & Material Expert & 2.91 (Valid) & 3 (Valid) & 2.92 (Valid) & 3 (Valid) & 2.96 (Valid) \\
\hline & Language Expert & 2.55 (Valid) & 2.75 (Valid) & 2.85 (Valid) & 2.95 (Valid) & 2.78 (Valid) \\
\hline & Media Expert & 2.86 (Valid) & 3 (Valid) & 3 (Valid) & 3 (Valid) & 2.97 (Valid) \\
\hline & Design Expert & 3 (Valid) & 2.94 (Valid) & 3 (Valid) & 3 (Valid) & 2.99 (Valid) \\
\hline & Average & 2.83 (Valid) & 2.92 (Valid) & 2.94 (Valid) & 2.95 (Valid) & 2.92 (Valid) \\
\hline$B$. & \multicolumn{6}{|c|}{ Practicality } \\
\hline & $\begin{array}{l}\text { Average score of } \\
\text { student response }\end{array}$ & $\begin{array}{l}4.36 \text { (Very } \\
\text { Practical) }\end{array}$ & 3.84 (Practical) & $\begin{array}{l}4.65 \text { (Very } \\
\text { Practical) }\end{array}$ & 4.1 (Practical) & $\begin{array}{l}4.24 \text { (Very } \\
\text { Practical) }\end{array}$ \\
\hline & $\begin{array}{l}\text { Average score of } \\
\text { student response }\end{array}$ & $\begin{array}{l}4.45 \text { (Very } \\
\text { Practical) }\end{array}$ & $\begin{array}{l}4.5 \text { (Very } \\
\text { Practical) }\end{array}$ & $\begin{array}{l}4.3 \text { (Very } \\
\text { Practical) }\end{array}$ & 4.15 (Practical) & $\begin{array}{l}4.35 \text { (Very } \\
\text { Practical) }\end{array}$ \\
\hline C. & \multicolumn{6}{|c|}{ Effectiveness } \\
\hline & $\begin{array}{l}\text { Average score of } \\
\text { students }\end{array}$ & 83.5 (Pass) & 84.5 (Pass) & 82.5 (Pass) & 83 (Pass) & 83.34 (Pass) \\
\hline & $\begin{array}{l}\text { Number of passing } \\
\text { students }\end{array}$ & $8 / 10$ & $9 / 10$ & $7 / 8$ & $7 / 8$ & $31 / 36$ \\
\hline & Percentage of Passing & $80 \%$ & $90 \%$ & $87.5 \%$ & $87.5 \%$ & $86.1 \%$ \\
\hline
\end{tabular}




\section{Discussion}

The final prototype digital book is a revised result based on expert and user validation as well as self-evaluation. Qualitative inputs from both the expert and the user were collected and used directly to revise the digital book draft. Important input from experts namely: (1) material expert: the selection of illustrations or examples must be considered, (2) language expert: there are uncommon words and sentences, therefore, simpler words and sentences are needed, (3) learning design expert: instructions of each learning activity must be clarified, and (4) media expert: fonts, image sizes, graphics, and animations must be adjusted so that they are proportional to the book layout. Feedback from teachers as users namely: (1) the language used must be simplified, and (2) the questions must be arranged from the easiest questions to the most difficult questions. Meanwhile, the feedback from students can be seen from the activities and reactions after using the digital book. They seemed interested and excited in reading material descriptions, watching videos, and trying GeoGebra simulations in books. They become happy to learn mathematics with a developed digital book.

The quantitative results of digital book quality can be seen in Table 3 which showed that the developed digital book was feasible because of its met validity, practicality, and effectiveness criteria. There were 4 aspects of validity namely content, learning design, media (graphics), and language. The average validity score of content was 2.96 . The feasibility of content was very high with a percentage of $98.7 \%$. This means, from the material aspect, the developed digital book was in accordance with the material feasibility indicator. According to the validator, the material is in accordance with the applicable curriculum. In addition, the correctness of the concepts, accuracy, breadth, depth, and clarity of the material were excellent. The average validity score of language was $2.78(92.7 \%)$ or very high. This means, from the language aspect, the developed digital book was in accordance with the language indicators. According to the validator, sentence structure, vocabulary, sentence effectiveness, spelling accuracy and familiarity of terms were excellent. The average validity score of learning design was $2.97(99 \%)$. According to the validator, (1) the presentation is in accordance with the objectives, material, evaluation, and syllabus presentation systematics, (2) the material is conveyed effectively, clearly, systematically and does not cause multiple interpretations, and (3) clear learning instructions. The average validity score of media was $2.92(97.3 \%)$. This means, from the media aspect, font, image display, layout, graphics, animation, and illustration were coherent and proportional.

Based on the practicality test, teachers and students as book users very agreed if this digital book is used as a learning resource for deaf students. The average score of teacher response was $4.35(87 \%)$ and the average score of student response was 4.24 (84.8\%). The questionnaire for the teacher consisted of 20 statements. Teachers strongly agreed that (1) the digital book can help teachers in learning mathematics for deaf students, (2) the book is in accordance with the mathematics curriculum in special school, (3) the digital book is easy to use, (4) the book has the appearance of interesting and easy to understand, and (5) the book is in accordance with the characteristics of deaf students. Students very agreed that the book is (1) easy to understand, 
(2) easy to use, (3) interesting, and (4) fun. Some of the factors causing the positive response from users to this digital book namely (1) the display of the digital book which imitates the printed book as stated by [40] will make the student learning transition faster, (2) it will be possible for this digital book to be played on a smartphone as stated by [41] makes learning more flexible, and (3) providing learning videos equipped with sign language which make learning interesting and fun [42].

The effectiveness of the book was measured by testing 9 students. The average score was 83.34 with the percentage of classical completeness was $86.1 \%$. The results indicated that the digital book was effective in improving the learning outcomes of deaf students. Digital books were easily understood by students with very good mastery of the material. The very good mastery of the material is caused by (1) presentation material with a multi-representative approach can build a deeper understanding of concepts [16], [43]-[45], (2) the book is equipped with learning videos which according to [46]-[49] is effective for improving learning outcomes, and (3) the digital book is equipped with GeoGebra media which according to [50]-[52] is effective in increasing the motivation and learning outcomes of students.

Thus, this study developed a prototype interactive digital book with valid, practical, and effective criteria so that it can be said that the digital book was feasible. The results of this study can be a solution to the scarcity of teaching materials specifically for deaf students [53], especially for mathematical learning. The developed digital book is a refinement of interactive media specifically for learning mathematics for deaf students as developed by [38], [54], [55]. In the previous study, the developed media was not yet an adaptive player because it could only be played on computers with the Windows/Mac/Linux operating system. The developed digital book is an adaptive player, besides being able to be played on a computer, this media can also be played on a smartphone so that it is more flexible than computer-based media [41], [56]-[61]. The new innovation in this digital book compared to the previous media is the use of the multi representation approach. According to [16], the use of more than one representation in presenting a mathematical idea can reduce the misinterpretation of the students in absorbing information. Further studies need to be done to follow up on the results of this first-year study. Large group testing involving larger groups needs to be performed immediately in order to obtain strong empirical evidence regarding the effectiveness of digital books in enhancing mathematics learning achievement of deaf students.

\section{Conclusion}

The developed interactive digital mathematics book with multi representation approach met feasibility criteria based on validity, practicality, and effectiveness criteria. Experts assessed content validity, language validity, learning design validity, and media validity with valid criteria. The users assessed that the digital book was very practical and the test results showed the effectiveness of the book to improve learning outcomes. Large group testing needs to be performed immediately to obtain strong 
empirical evidence regarding the effectiveness of digital books in improving mathematics learning outcomes of deaf students.

\section{Acknowledgements}

Gratitude is expressed to (1) Ministry of Research and Technology /National Research and Innovation Agency of the Republic of Indonesia for the funding, (2) SLB Negeri 1 Singaraja as a subject, and (3) sign language translator.

\section{$7 \quad$ References}

[1] D. Astuti, "Pengembangan Bahan Ajar Matematika Untuk SMPLB/B Kelas IX Berdasarkan Standar Isi," in PROSIDING, Seminar Nasional Matematika dan Pendidikan Matematika, 2013, pp. 211-218. https://doi.org/10.20527/edumat.v5i1.3825

[2] A. Tanridiler, Y. Uzuner, U. G.-T. Anthropologist, and undefined 2015, "Teaching and learning mathematics with hearing impaired students," Taylor Fr., Accessed: Aug. 18, 2019. [Online]. Available: https://www.tandfonline.com/doi/abs/10.1080/09720073.2015. 11891874. https://doi.org/10.1080/09720073.2015.11891874

[3] I. Pujawan, I. Suryawan, and D. A. A. Prabawati, "The Effect of Van Hiele Learning Model on Students' Spatial Abilities.," Int. J. Instr., vol. 13, no. 3, pp. 461-474, 2020. https://doi.org/10.29333/iji.2020.13332a

[4] T. Nunes, C. M.-J. of D. S. and Deaf, and undefined 2002, "An intervention program for promoting deaf pupils' achievement in mathematics," academic.oup.com, Accessed: Aug. 18, 2019. [Online]. Available: https://academic.oup.com/jdsde/article-abstract/7/2/120/381 $\underline{470} \cdot \underline{\text { https: } / / \text { doi.org/10.1093/deafed/7.2.120 }}$

[5] I. R.-I. journal of pediatric otorhinolaryngology and undefined 1986, "Helping deaf children acquire language: Lessons from the past," Elsevier, Accessed: Aug. 18, 2019. [Online]. Available: https://www.sciencedirect.com/science/article/pii/S016558768680017 $\underline{9}$.

[6] I. M. Suarsana, I. G. W. Sudatha, G. A. Mahayukti, and R. A. Apsari, "Mathematical word problem solving abilities of hearing-impaired students," in Journal of Physics: Conference Series, 2021, vol. 1778, no. 1, p. 12006. https://doi.org/10.1088/1742-6596/1778/1/012006

[7] S. Saud, ... Z. N. U. S. and E. (i, and undefined 2016, "Design of e-learning courseware for hearing impaired (HI) students," ieeexplore.ieee.org, Accessed: Aug. 18, 2019. [Online]. Available: https://ieeexplore.ieee.org/abstract/document/7857973/.

[8] Y. T. Chen, "A study to explore the effects of self-regulated learning environment for hearing-impaired students," J. Comput. Assist. Learn., vol. 30, pp. 97-109, 2014.

[9] W. H. Chan and T. J. Chou, "Model of school adjustment of students with learning disabilities and general students in senior high and/or vocational school students," J. Spec. Educ., vol. 24, pp. 113-134, 2006.

[10] C. D. Reuterskiold, T. D. Ibertsson, and B. D. Sahlen, "Venturing beyond the sentence level: Narrative skills in children with hearing loss.," Volta Rev., vol. 110, no. 3, pp. 389406, 2010. https://doi.org/10.17955/tvr.110.3.638

[11] Y. Pariatin and Y. Z.A., "Perancangan Media Pembelajaran Interaktif Mata Pelajaran PKN untuk Penyandang Tuna Rungu Berbasis Multimedia," J. Algoritm., vol. 11, pp. 10-19, 2011. https://doi.org/10.33364/algoritma/v.11-1.1 
[12] B. R. Malatista and E. Sediyono, "Model Pembelajaran Matematika untuk Siswa Kelas IV SDLB Penyandang Tunarungu dan Wicara dengan Metode Komtal Berbantuan Komputer," J. Inform., vol. 7, no. 1, p. 7, 2012.

[13] K. Hopkins and B. C. Moore, "Development of a fast method for measuring sensitivity to temporal fine structure information at low frequencies," Int. J. Audiol., vol. 49, no. 12, pp. 940-946, 2010. https://doi.org/10.3109/14992027.2010.512613

[14] Kartini, "Peranan Representasi Dalam Pembelajaran Matematika," 2009.

[15] M. Sabirin, "Representasi dalam pembelajaran matematika," J. Pendidik. Mat. UIN Antasari, vol. 1, no. 2, pp. 33-44, 2014. https://doi.org/10.18592/jpm.v1i2.49

[16] S. Ainsworth, "The functions of multiple representations," Comput. Educ., vol. 33, no. 2 , pp. 131-152, 1999.

[17] D. P. Darmastini, "Multi representasi siswa smp dalam menyelesaikan soal terbuka matematika ditinjau dari perbedaan gender," MATHEdunesa, vol. 1, no. 3, 2014. https://doi.org/10.26740/mathedunesa.v9n2.p382-391

[18] N. P. I. Cahyani, I. M. Suarsana, and G. A. Mahayukti, "Improving Student's Mathematical Problem-Solving Skills Through Relating-Experiencing-ApplyingCooperating-Transferring Learning Strategy and Graphic Organizer," in First International Conference on Science, Technology, Engineering and Industrial Revolution (ICSTEIR 2020), 2021, pp. 337-344. https://doi.org/10.2991/assehr.k.210312.056

[19] Pearson, "Beyond Millennials: The Next Generation of Learners Beyond," Glob. Res. Insights, no. August, pp. 1-21, 2018.

[20] M. R. Nelson, "E-books in higher education: nearing the end of the era of hype?, Educ. Rev., vol. 43, no. 2, pp. 40-42, 2008.

[21] N. Hasyim and A. Muqoddas, "Inventarisasi Cerita Rakyat dari Kabupaten Demak melalui Aplikasi Buku Digital (E-Book) Interaktif," Andharupa J. Desain Komun. Vis. Multimed., vol. 1, no. 02, pp. 142-151, 2015. https://doi.org/10.33633/andharupa.v1i0 $\underline{2.965}$

[22] N. N. Aziz, Z. A. Shaffiei, N. H. M. Roseli, N. U. A. Aziz, A. A. Mutalib, and M. S. Jaafar, "Assistive Courseware for Hearing Impaired Learners in Malaysia," Int. J. Adv. Sci. Eng. Inf. Technol., vol. 1, no. 2, pp. 133-138, 2011. https://doi.org/10.18517/ijaseit.1.2.30

[23] S. F. Saud and Z. A. Nasruddin, "Design of e-learning courseware for hearing impaired (HI) students," in In User Science and Engineering (i-USEr), 2016 4th International Conference, 2016, pp. 271-276. https://doi.org/10.1109/iuser.2016.7857973

[24] A. Rusli and B. Waldrip, "Implementasi pembelajaran berbasis multi representasi untuk peningkatan penguasaan konsep fisika kuantum," J. Cakrawala Pendidik., vol. 1, no. 1, 2011. https://doi.org/10.21831/cp.v1i1.4189

[25] D. Corradi, J. Elen, and G. Clarebout, "Understanding and enhancing the use of multiple external representations in chemistry education," J. Sci. Educ. Technol., vol. 21, no. 6, pp. 780-795, 2012. https://doi.org/10.1007/s10956-012-9366-Z

[26] M. I. S. Putra, "Efektivitas Pembelajaran Statistik dengan Pendekatan Keterampilan Multi Representasi untuk Meningkatkan Hasil Belajar Mahasiswa PGMI UNIPDU Jombang," JMPM J. Mat. dan Pendidik. Mat., vol. 1, no. 1, pp. 65-75, 2016. https://doi.org/10.2659 4/jmpm.v1i1.515

[27] T. NURROHMAN, "Pengembangan Model Pembelajaran Konseptual Saintifik Berbasis Representasi Jamak Untuk Peningkatan Penguasaan Konsep Fisika Dan Keterampilan Proses Sains Siswa Kelas X SMAN 1 Kalirejo." Universitas Lampung, 2016. https://doi.org/10.24127/jpf.v2i2.125

[28] D. Permadi and K. Setyaningsih, "Pengembangan Modul Multi Representasi Berbasis Kontekstual Pada Materi Fluida Statis Untuk Meningkatkan Kemampuan Berpikir Kritis," 
JIFP (Jurnal Ilmu Fis. dan Pembelajarannya), vol. 1, no. 2, pp. 5-10, 2017. https://doi.org/10.20961/inkuiri.v7i2.31680

[29] D. M. B. Perdana, "Pengembangan Buku Digital Interaktif (BUDIN) Berbasis Adobe Creative Suite pada Materi Genetika di SMK." Universitas Negeri Semarang, 2013.

[30] R. Riyanto, M. Amin, H. Suwono, and U. Lestari, "The new face of digital books in genetic learning: a preliminary development study for students' critical thinking," Int. J. Emerg. Technol. Learn., vol. 15, no. 10, p. 175, 2020. https://doi.org/10.3991/ijet.v15i1 $\underline{0.14321}$

[31] C. H. Miller, "Digital storytelling: a creator's guide to interactive entertainment (Vol. 3rd)." Burlington, Mass: Focal Press, 2014.

[32] S. Wijayanti, N. Fadiawati, and L. Tania, "Pengembangan E-book Interaktif Kesetimbangan Kimia Berbasis Representasi Kimia," J. Pendidik. dan Pembelajaran Kim., vol. 4, no. 2, pp. 481-492, 2015. https://doi.org/10.31227/osf.io/b8d5e

[33] N. Jannah, N. Fadiawati, and L. Tania, "Pengembangan E-book Interaktif Berbasis Fenomena Kehidupan Sehari-hari tentang Pemisahan Campuran," J. Pendidik. dan pembelajaran Kim., vol. 6, no. 1, pp. 186-198, 2017.

[34] W. A. Indhaka, E. Supraptono, and N. Sugiarti, "Penerapan buku sekolah elektronik berbasis android dalam materi ajar besaran dan satuan," J. Penelit. Tindakan Kelas, vol. 17, no. 2, 2016.

[35] S. Sunismi and A. H. Fathani, "Prototipe model collaborative learning matematika melalui media blog dengan interactive digital book mata kuliah kalkulus II," J. Fourier, vol. 6, no. 2, pp. 69-83, 2017. https://doi.org/10.14421/fourier.2017.62.69-83

[36] U. Nafiáh, M. Mashuri, and D. N. Wijaya, "The Development of Digital Book of European History to Shape the Students' Democratic Values.," iJET, vol. 14, no. 6, pp. 147-154, 2019. https://doi.org/10.3991/ijet.v14i06.9760

[37] S. Thiagarajan, "Instructional development for training teachers of exceptional children: A sourcebook.," 1974.

[38] I. M. Suarsana, G. A. Mahayukti, K. Sudarma, and N. B. A. Yoga, "Development of Interactive Mathematics Learning Media on Statistics Topic for Hearing-impaired Student I Made Suarsana a," Int. Res. J. Eng. IT Sci. Res., vol. 4, no. 6, pp. 55-66, 2018, https://doi.org/10.21744/irjeis.v4n6.377.

[39] J. Y. Kharisma and A. Asman, "Pengembangan Bahan Ajar Matematika Berbasis Masalah Berorientasi pada Kemampuan Pemecahan Masalah Matematis dan Prestasi Belajar Matematika," Indones. J. Math. Educ., vol. 1, no. 1, pp. 34-46, 2018. https://doi.org/10. 31002/ijome.v1i1.926

[40] H. Henke, Electronic books and ePublishing: a practical guide for authors. Springer Science \& Business Media, 2001.

[41] J. R. Meilana, "Pengembangan Modul Mobile Learning Berbasis Android Pada Materi Fluida Statis," 2017.

[42] N. M. L. K. Putri, D. P. Parmiti, and I. K. Sudarma, "Pengembangan Video Pembelajaran dengan Bahasa Isyarat Berbasis Pendidikan Karakter pada Siswa Kelas V di SDLB-B Negeri I Buleleng Tahun Pelajaran 2017/2018," J. EduTech Undiksha, vol. 7, no. 2, pp. 81-91, 2020. https://doi.org/10.23887/jeu.v8i1.25393

[43] I. M. Suarsana, G. A. Mahayukti, I. K. Sudarma, and A. A. G. S. Pujawan, "The Effect of Interactive Mathematics Learning Media toward Mathematical Conceptual Understanding on Probability of Hearing-impaired Students," J. Phys. Conf. Ser., vol. 1165, p. 012021, Feb. 2019, https://doi.org/10.1088/1742-6596/1165/1/012021.

[44] I. K. Y. Sumalasia, I. M. Suarsana, and I. W. P. Astawa, "Pengembangan bahan ajar interaktif multi representasi pada materi geometri kelas VII SMPLB Tunarungu," 
Pythagoras J. Pendidik. Mat., vol. 15, no. 1, 2020. https://doi.org/10.21831/pg.v15i1.25 $\underline{851}$

[45] G. P. Suarcita, I. W. P. Astawa, and I. M. Suarsana, "pengembangan bahan ajar digital interaktif dengan pendekatan multi representasi pada materi bilangan bulat untuk siswa smplb tunarungu kelas VII," Akademika, vol. 9, no. 01, pp. 69-84, 2020. https://doi.org/10. 34005/akademika.v9i01.731

[46] D. Pangga, S. Ahzan, and L. Pratama, "Efektifitas Penerapan Video Pembelajaran Terhadap Hasil Belajar Dan Pemahaman Konsep Fisika Siswa," ORBITA J. Kajian, Inov. dan Apl. Pendidik. Fis., vol. 6, no. 1, pp. 155-158, 2020. https://doi.org/10.31764/orb ita.v6i1.1510

[47] J. Hildebrand and B. Ahn, "Student video viewing habits in an online mechanics of materials engineering course," 2018.

[48] S. Jati, A. Subekti, and W. Sulistyo, "Development of'Video Bank’Based on Prehistoric Community Life at the Sangiran Site as an Independent Learning Media," Int. J. Emerg. Technol. Learn., vol. 15, no. 7, pp. 86-97, 2020. https://doi.org/10.3991/ijet.v15i07.13257

[49] R. H. Kay, "Developing a Framework for Creating Effective Instructional Video Podcasts.," Int. J. Emerg. Technol. Learn., vol. 9, no. 1, 2014. https://doi.org/10.3991 /ijet.v9i1.3335

[50] R. Rhilmanidar, M. Ramli, and B. I. Ansari, "Efektivitas Modul Pembelajaran Berbantuan Software GeoGebra pada Materi Bangun Ruang Sisi Datar," J. Didakt. Mat., vol. 7, no. 2 , pp. 142-155, 2020. https://doi.org/10.24815/jdm.v7i2.17915

[51] C. Manganyana, S. van Putten, and W. Rauscher, "The Use of GeoGebra in Disadvantaged Rural Geometry Classrooms,” Int. J. Emerg. Technol. Learn., vol. 15, no. 14, pp. 97-108, 2020. https://doi.org/10.3991/ijet.v15i14.13739

[52] D. Velichová, "Interactive Maths with GeoGebra," iJET, vol. 6, no. 1, pp. 31-35, 2011.

[53] D. Astuti, "Pengembangan Bahan Ajar Matematika untuk SMPLB/B Kelas IX Berdasarkan Standar Isi.” Tidak Diterbitkan. Skripsi. Yogyakarta: Universitas Negeri Yogyakarta, 2010.

[54] K. Beni, I. N. Gita, and I. M. Suarsana, "Media Pembelajaran Matematika Interaktif untuk Siswa Tunarungu: Perancangan dan Validasi," 2017. Accessed: Jan. 26, 2020. [Online]. Available: http://pti.undiksha.ac.id/senapati.

[55] A. A. G. S. Pujawan, I. M. Ardana, and I. M. Suarsana, "Pengembangan Media Pembelajaran Interaktif Materi Peluang Untuk Meningkatkan Pemahaman Konsep Siswa SMPLB Tunarungu," ejournal.undiksha.ac.id, Accessed: Jan. 26, 2020. [Online]. Available: https://ejournal.undiksha.ac.id/index.php/JJPM/article/view/13091. https://doi.o rg/10.23887/jipm.v9i2.19896

[56] H. Hernawan, "Penggunaan Aplikasi Mobile Learning Berbasis Html 5 Untuk Meningkatkan Pemahaman Mahasiswa pada Mata Kuliah Mikrobiologi," PEDAGOGIA, vol. 15, no. 2, pp. 124-131, 2017. https://doi.org/10.17509/pedagogia.v15i2.8090

[57] N. Ibrahim and I. Ishartiwi, "Pengembangan Media Pembelajaran Mobile Learning Berbasis Android Mata Pelajaran IPA untuk Siswa SMP," Refleks. Edukatika J. Ilm. Kependidikan, vol. 8, no. 1, 2017. https://doi.org/10.24176/re.v8i1.1792

[58] D. A. Wulandari, H. Wibawanto, and H. Suryanto, "Pengembangan Mobile Learning berbasis Android pada Mata Pelajaran Rekayasa Perangkat Lunak di SMK Sultan Trenggono Kota Semarang," J. Teknol. Inf. dan Ilmu Komput., vol. 6, no. 5, 2019. https://doi.org/10.25126/jtiik.201965994

[59] K. Saraubon, P. Nilsook, and P. Wannapiroon, "System Design of Mobile Augmented Book.," Int. J. Interact. Mob. Technol., vol. 10, no. 1, 2016. https://doi.org/10.3991/i jim.v10i1.5276 
[60] R. Ristanto, R. Rusdi, R. Mahardika, E. Darmawan, and N. Ismirawati, "Digital Flipbook Imunopedia (DFI): A Development in Immune System e-Learning Media," 2020. https://doi.org/10.3991/ijim.v14i19.16795

[61] J. Bidarra, M. Figueiredo, and C. Natálio, "Interactive design and gamification of ebooks for mobile and contextual learning," Int. J. Interact. Mob. Technol., pp. 24-32, 2015. https://doi.org/10.3991/ijim.v9i3.4421

\section{Author}

I Made Suarsana is an active researcher on learning mathematics, learning technology and learning for deaf students. He has published some writings at international conferences and in reputable journals such as International Journal of Instruction, Journal on Mathematics Education and Journal of Physics: Conference Series.

Article submitted 2021-03-05. Resubmitted 2021-04-05. Final acceptance 2021-04-07. Final version published as submitted by the authors 